\title{
A brief history of South Africa's response to AIDS
}

\author{
N P Simelela, ${ }^{1} \mathrm{MB}$ ChB, MMed; W D F Venter, ${ }^{2}$ FCP (SA) \\ ${ }^{1}$ Special Adviser on Health Matters within the Presidency and former Chief Director of HIV \& AIDS within the National Department of Health \\ ${ }^{2}$ Wits Reproductive Health and HIV Institute and Department of Medicine, Faculty of Health Sciences, University of the Witwatersrand, \\ Johannesburg, South Africa
}

Corresponding author: N P Simelela (nonosimelela@gmail.com)

\begin{abstract}
The story of the AIDS response in South Africa over the past 4 years is one of great progress after almost a decade of complex and tragic denialism that united the world and civil society in a way not seen since the opposition to apartheid. Today the country can boast $>2$ million people on antiretroviral therapy, far and away the largest number in the world. Prevention efforts appear to be yielding results. The estimated number of annual new HIV infections declined by 79000 between 2011 and 2012. New HIV infections among adults aged 15 - 49 years are projected to decline by $48 \%$ by 2016, from 414000 (2010) to 215000 (2016). The national incidence rate has reached its lowest level since the disease was first declared an epidemic in 1992, translating into reductions in both infant and under-5 mortality and an increase in life expectancy from 56 to 60 years over the period 2009 - 2011 alone. This is largely thanks to a civil society movement that was prepared to pose a rights-based challenge to a governing party in denial, and to brave health officials, politicians and clinicians working in a hostile system to bring about change.
\end{abstract}

S Afr Med J 2014;104(3 Suppl 1):249-251. DOI:10.7196/SAMJ.7700

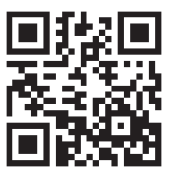

South Africa (SA) is home to the largest concentration of people living with HIV anywhere in the world. Almost $20 \%$ of all HIV-positive persons globally live within our borders, and preliminary data from the as yet unreleased 2012 Human Sciences Research Council South African National Household Survey reveal that $>6.4$ million people in SA $-19.6 \%$ of all adults or $12.3 \%$ of the total population - live with the virus. ${ }^{[1]}$

The first AIDS-related deaths in SA occurred in late December 1981 and January 1982, with very limited attention to the epidemic over the next decade. ${ }^{[2,3]}$ The dawn of a new democracy in 1994 brought optimism regarding the future of the country, and the new administration had to redesign every tier of government in the context of a fractured governance system that included the so-called 'Bantustans. The HIV epidemic was not an issue of major concern and therefore received very limited attention in the initial flurry of setting up a democratic government.

Civil society created a National Advisory Group (Networking HIV/AIDS Community of South Africa (NACOSA)) to lobby for and ultimately to draft a national AIDS plan. This plan was accepted by the new government 3 months into its term of office in $1994 .{ }^{[2]} \mathrm{HIV}$ prevalence subsequently rose from $0.8 \%$ in 1990 to $4.3 \%$ by 1994 , and now rests at $12.3 \%$ of the total population. ${ }^{[1]}$ Tragically, $1998-2008$ was to prove a testing period for the country as the full extent of the epidemic's health impact became apparent, in the face of President Thabo Mbeki's increasingly apparent denialism. ${ }^{[4]}$

\section{The beginning of a prevention and treatment response}

Given the limited knowledge regarding HIV transmission dynamics, the mainstay of the response during the 1980s and 1990s was the provision of condoms and a 'safe-sex' education strategy hampered by stigma, fear and other behavioural and social factors. Efforts to communicate were additionally impeded by controversies around the Sarafina II play ${ }^{[5]}$ and the Virodene scandals. ${ }^{[2]}$ Efforts to mitigate the impact of the epidemic included a strategy for home-based care for the large number of people who had advanced AIDS, and strategies for affected children.

The second phase of the prevention response followed, with trials examining the effectiveness of antiretrovirals (ARVs) delivered to pregnant women and their neonates (prevention of mother-to-child transmission (PMTCT)), and ushered in an era of heightened conflict. ${ }^{[6,7]}$ The SA government declared that a phased piloting approach was needed, and there was enough scientific evidence confirming the efficacy of ARVs in reducing the transmission of HIV from mother to child that it should be implemented within the region immediately, but the operational challenges of actually introducing PMTCT needed to be assessed in both rural and urban settings'; this phased approach was seen as an attempt to hamper expanding rapid access to effective PMTCT. The decision came at the height of civil society's clash with Mbeki's administration over widely criticised denialism on the issue of HIV/AIDS, including denial of a causal link between HIV and AIDS.

Civil society challenged the policy in the High Court, arguing that the refusal to provide nevirapine for the PMTCT violated the Constitution. The Pretoria High Court ruled that '[a] countrywide PMTCT programme is an ineluctable obligation of the state. The Minister of Health appealed this ruling directly to the Constitutional Court, claiming that an appeal was necessary to '[clarify] a constitutional and jurisdictional matter which, if left vague, could throw executive policy making into disarray and create confusion about the principle of the separation of powers, which is a cornerstone of our democracy?'

During the appeal, a Health Systems Trust report commissioned by the National Department of Health $(\mathrm{NDoH})$ stated categorically that 'There are no good reasons for delaying a phased expansion of PMTCT services in all provinces', and recommended that 'nevirapine can and should be provided immediately. ${ }^{\left[{ }^{[8]}\right.}$ Gauteng and KwaZuluNatal provinces broke ranks with Minister of Health $(\mathrm{MoH})$, Dr Manto Tshabalala-Msimang, and announced decisions to expand their PMTCT pilot programmes. ${ }^{[9]}$ Even though the Gauteng Premier received a public rebuke from the $\mathrm{MoH}$ and gave the appearance of 
backing down, it was soon announced that PMTCT was available at $70 \%$ of public healthcare facilities in Gauteng. The Minister lost the appeal in a historic judgment that remains unprecedented in its criticism of the government. ${ }^{[7]}$

In the face of sustained national and international criticism, as well as internal dissent, and as countries in southern Africa began announcing public antiretroviral therapy (ART) programmes, a Cabinet statement released in April 2002 'reiterated government's commitment to the HIV \& AIDS and STI Strategic Plan for South Africa, 2000 - 2005' and affirmed that 'government's starting point is based on the premise that HIV causes AIDS. ${ }^{[10]}$ This statement signalled a sea-change within the government on HIV. The same Cabinet meeting called on the $\mathrm{NDoH}$ to develop a rollout plan for the PMTCT and, unexpectedly, to prepare a protocol for a comprehensive package of care for survivors of sexual assault, including post-exposure prophylaxis with ARV drugs' which would, for the first time, make prophylaxis available to survivors of sexual assault in public healthcare facilities across all nine provinces.

\section{The development of an ART programme}

Later in April 2002, the SA government established a Joint Health and Treasury Task Team to propose options for expanding the HIV treatment response beyond PMTCT and post-exposure prophylaxis. Clinicians in the joint task team quietly developed HIV treatment protocols that included ART for adults and children. Assistance from the Clinton Foundation and other international agencies, including donors such as the US President's Emergency Plan for AIDS Relief (PEPFAR), allowed this work to progress rapidly. In August 2003 Cabinet received the joint Health and Treasury Task Team report. ${ }^{[1]}$ The Cabinet meeting reaffirmed the government's position on the causal link between HIV and AIDS, and instructed the NDoH to develop 'as a matter of urgency' a detailed operational plan for a nationwide ART programme. ${ }^{[12]}$

In November 2003 the Operational Plan for Comprehensive HIV and AIDS Care, Management and Treatment for South Africa ${ }^{[13]}$ was presented to and approved by Cabinet. ${ }^{[14,15]}$ Finally, on 1 April 2004, ARV initiation began at several service points across the country. Facilities had to be 'accredited', needing to pass an exhaustive examination of 23 different criteria. ${ }^{[1,16]}$ The intention behind the accreditation was to enable facilities to prepare adequately, but the process slowed down the pace of expansion considerably. The implementation approach created significant verticalisation of the programme and set the tone of the response, requiring teams of specialist healthcare workers and complicated bureaucratic procedures, and putting challenging staffing and infrastructure obstacles in the way of delivery.

\section{The ART programme begins}

By March 2005, the target of the comprehensive plan - to have at least one service point for AIDS-related care and treatment in each of the country's 53 districts - had been met. It took 12 months after the rollout began, and was more than 2 years after the Operational Plan was developed, to meet this target. All provinces had begun providing ART, but this was largely through hospitals, a large number of them tertiary facilities. The number of people actually receiving ART remained far below what had been targeted. By September 2005, 17 months after rollout began, 85000 people were enrolled on ART in the public health sector. By then, 199 public healthcare facilities (just over 5\%) were providing ARVs for the treatment of HIV. ${ }^{[1]]}$ The NDoH issued a directive in 2005 instructing facilities that possession of an ID book was not a requirement for treatment, allowing foreign nationals to access the ART programme. Donors such as PEPFAR and the Global Fund continued to support a broad array of interventions, including support to large non-governmental organisations, to support and provide care.

In 2006, Cabinet signed off on the new National Strategic Plan (NSP) for HIV \& AIDS and STIs, 2007 - 2011, prepared by the South African National AIDS Council (SANAC) in a laborious, politically charged but widely consultative process. The NSP ambitiously committed the government to providing ARVs to $80 \%$ of those eligible. By December 2007, an estimated 424009 patients were receiving ARVs.

The year 2008 was a landmark for the HIV programme. A leadership transition in the ANC saw the resignation of President Mbeki and his $\mathrm{MoH}$ and the installation of an interim government between September 2008 and May 2009. By December 2008, the estimated number of patients on ARVs had grown to 678550.

In May 2009, the newly installed President Jacob Zuma immediately acknowledged HIV as among the most important challenges facing the country, and Dr Aaron Motsoaledi, appointed as $\mathrm{MoH}$, brought an urgency and a renewed focus to the HIV response. The new $\mathrm{MoH}$ began his tenure by frankly acknowledging that SA's healthcare system had spent the last ' 10 years pedalling backwards ${ }^{\text {[17] }}$ and began freely citing the extensive HIV data available from the SA research community, as well as several highly influential and critical reviews on the country's health system published in The Lancet. During his address to the National Council of Provinces in 2009, the President highlighted 'the chilling statistics that demonstrate the devastating impact that HIV and AIDS is having on our nation'. He declared World AIDS Day 2009 as 'the day on which we start to turn the tide in the battle against AIDS.

With the number of patients on ARVs estimated to be $>900000$, SA launched a massive national HIV counselling and testing (HCT) campaign. The sheer scale of patients anticipated to be identified by the campaign led to the announcement that accreditation would be abandoned and that all public healthcare facilities would be geared up to provide ARVs. As part of the HCT campaign, the President publicly tested for HIV, among the 20 million South Africans to learn their status over the next 20 months.

This announcement included the declaration that the country would launch a medical male circumcision drive, with KwaZuluNatal the first province to roll this out at scale, although this process was hampered by controversy over the use of a circumcision device that many felt was unsafe. By the end of 2010, 131117 men had been circumcised. At the end of the year, in sharp contrast to the booing President Mbeki had received at the 2000 AIDS Conference, the Deputy President and $\mathrm{MoH}$ received a standing ovation at the Vienna AIDS conference after presenting the significant progress made in expanding access to treatment in SA.

With far less drama than had accompanied previous HIV guideline revisions, and signalling the 'normalisation' of the HIV policy response, the NDoH published guidelines relating to tuberculosis, PMTCT, HCT, community caregivers and circumcision, and moved towards 'task sharing' as part of primary healthcare restructuring. The year 2009 also saw the restructuring and strengthening of the SANAC, responsible for better co-ordination between civil society and government. The $\mathrm{NDoH}$ also revised the ARV guidelines in 2010, expanding treatment to all children under 1 year, all pregnant women regardless of $\mathrm{CD} 4^{+}$count and all TB-HIV co-infected patients with a $\mathrm{CD} 4^{+}$count of $<350$ cells/ $\mu \mathrm{l}$, and changing ART for both first- and second-line therapy to make it safer, if more expensive. Only $55 \%$ of adults and $36 \%$ of children eligible for ART were receiving it by the end of 2010.

On World AIDS Day 2011, SA launched a third NSP for 2012 2016, which included a strong focus on marginalised groups such as 
sex workers, men who have sex with men, truckers and adolescents. ${ }^{[13]}$ The head of the NDoH's HIV programme pointed to the dramatic acceleration of the programme, stating: 'It's actually quite extraordinary that in 2004 we had only 47000 people on treatment ... By mid-2011, we had 1.79 million people. It's almost a city. ${ }^{[18]}$ In 2012, a decision was made to increase the initiation threshold to 350 cells/ $\mu$ for all adults, as well as to expand access thresholds for children. By mid-2013, 6.4 million people were estimated to be living with HIV in SA, with an estimated 2.3 million on ART, and expanded access to 'third-line' drugs for patients experiencing resistance.

\section{Conclusion}

Huge challenges remain for the HIV response. HIV care provision requires a functional healthcare service, and failures threaten the existing and further scale-up of ARV care. Having access to worldclass medication and initiation thresholds is small comfort when reports from across the country of drug stock-outs suggest a major problem in supply systems well beyond HIV care. ${ }^{[19]}$ Some high-risk sexual behaviours seem to be on the rise. ${ }^{[1]}$ Key populations, such as sex workers, men who have sex with men, truckers, adolescents, heterosexual men and others are not accessing services enough. Addressing the structural factors that increase vulnerability is the main focus of the development agenda going forward. Enablers such as poverty, unemployment, alcohol abuse, gender violence, teenage pregnancy and access to evidence-based interventions such as male circumcision and condoms need to be addressed. Monitoring and evaluation remain rudimentary, with constant speculation that high initiation numbers mask large numbers of patients lost to follow-up.

Cost remains an issue. ${ }^{[20]}$ In retrospect, the progressive evolution of the HIV and AIDS conditional grant over several years into a flexible, simplified funding mechanism was probably critical to finding a financing vehicle capable of successfully channelling hundreds of millions of rands into the new comprehensive treatment programme in the space of just a year or two. This had not been the deliberate intent of those who had nurtured the grant from a R16 million infant to the R8.7 billion behemoth it has become in 2013/14, ${ }^{[21]}$ but the grant mechanism appears to have endured successfully.

Since 2009, a new administration has rapidly normalised the response to the epidemic. The political and science battles appear largely to have been fought; ${ }^{[22,23]}$ the harder job of ensuring a system of delivery that secures decades of effective HIV prevention and care now looms as possibly the greater challenge.
Acknowledgments. NPS writes in her personal capacity. WDFV is supported by PEPFAR.

1. Mabhena N, Ndirangu J, Mutevedzi P. Presentation, Track 3: Epidemiology and Prevention. Presented during the Closing Plenary of the 6th South African AIDS Conference, Durban, South Africa, 21 June 2013. http://www.saaids.co.za/images/stories/aids2013/presentations/plenary5/Track_3_Epidemiology_ nd_Prevention.pdf (accessed 3 February 2014).

2. McNeil I. A history of official government HIV/AIDS policy in South Africa. South African History Archives. http://www.sahistory.org.za/topic/history-official-government-hivaids-policy-south-africa
Antrican (accessed 30 January 2014)

3. Ras GJ, Simson W, Anderson R, Prozesky OW, Hamnersma T. Acquired immunodeficiency syndrome: A report of 2 South African cases. S Afr Med J 1983;64(4):140-114.

4. Furman K. Mbeki's AIDS denialism: Thabo Mbeki's support of dissident HIV/AIDS scientists is a cautionary tale for policy makers dealing with competing sets of evidence. Think Africa Press, 17 November 2011. http://thinkafricapress.com/south-africa/mbeki-aids-denialism (accessed 3 February 2014).

5. Health Systems Trust. Phila Legistative Update No. 3: The Sarafina II Controversy. June 1996. http://www. healthlink.org.za/pphc/Phila/sarafina.htmv (accessed 12 February 2014).

6. Barron P, Pillay Y, Doherty T, et al. Eliminating mother-to-child HIV transmission in South Africa. Bull World Health Organ 2013;91(1):70-74. [http://dx.doi.org/10.2471/BLT.12.106807]

7. Honermann B, Heywood M. A judgment that saved a million lives. The Star 2012, 5 July 2012. http://www.iol.co.za/the-star/a-judgment-that-saved-a-million-lives-1.1334636\#.UmWK8RD6oiQ (accessed 3 February 2014).

8. Health Systems Trust. Interim findings on the national PMTCT pilot sites, lessons and recommendations. February 2002, p. iv. http://www.hst.org.za/sites/default/files/PMTCT_Interim.pdf (accessed 3 February 2014)

9. Address by Premier Shilowa at the 2002 opening of the Gauteng Provincial Legislature. 18 February 2002. http://www.iol.co.za/news/politics/health-minister-slams-shilowa-s-aids-plan-1.82029\#.Uu9ftvmSySo (accessed 3 February 2014).

10. Statement on Cabinet meeting of 17 April 2002. http://www.gcis.gov.za/content/newsroom/mediareleases/cabinet-statements/statement-cabinet-meeting-17-april-2002-1 (accessed 22 January 2014).

11. Report of the Joint Health and Treasury Task Team on treatment options to enhance comprehensive care for HIV/AIDS in the public sector. http://www.gov.za/documents/download.php?f=70215 (accessed 3 February 2014)

12. Statement on Cabinet meeting of 8 August 2003. http://www.gcis.gov.za/content/newsroom/mediareleases/cabinet-statements/statement-cabinet-meeting-8-august-2003 (accessed 30 January 2014).

13. National Department of Health. The National Strategic Plan on HIV, STIs and TB, 2012 - 2016. 2011. http://www.sahivsoc.org/upload/documents/National_Strategic_Plan_2012.pdf (accessed 30 January 2014).

4he Operational Plan for Comprehensive HIV and AIDS Care, Management and Treatment for South Africa. 19 November 2003. http://www.gov.za/documents/download.php?f=164714 (accessed 5 February 2014)

15. Statement of Cabinet on a Plan for Comprehensive Treatment and Care for HIV and AIDS in South Africa. 19 November 2003. http://www.gcis.gov.za/content/newsroom/media-releases/cabinetstatements/cabinet-statement-treatplan-plan-hiv-and-aids (accessed 3 February 2014).

16. Implementation of the Comprehensive Plan on Prevention Treatment and Care of HIV and AIDS. Fact sheet 23 November 2005. http://www.gov.za/aboutgovt/programmes/hiv/implementation2006. htm (accessed 3 February 2014).

17. Bateman C. Time to 'stop pedalling backwards' - Motsoaledi. S Afr Med J 2009;99(11):778-779.

18. Health-e. NSP 2012-2016: Living with AIDS \#511. 12 April 2012. http://www.health-e.org. za/2012/04/12/nsp-2012-\%C2\%80\%C2\%93-2016-living-with-aids-511 (accessed 30 January 2014).

9. Bateman C. Drug stock-outs: Inept supply-chain management and corruption. S Afr Med J 2013;103(9):600-602. [http://dx.doi.org/10.7196/SAMJ.7332]

20. Meyer-Rath G, Over M. HIV treatment as prevention: Modelling the cost of antiretroviral treatment - state of the art and future directions. PLoS Med 2012;9(7):e1001247. [http://dx.doi.org/10.1371/ ournal.pmed.1001247]

21. National Treasury, Republic of South Africa. Budget Review 2012. http://www.treasury.gov.za/ documents/national\%20budget/2012/review/Prelims\%202012.pdf (accessed 22 January 2014).

22. UNAIDS, Republic of South Africa, 2014. http://www.unaids.org/en/regionscountries/countries/ southafrica/ (accessed 30 January 2014).

23. Mayosi BM, Lawn JE, van Niekerk A, et al., for The Lancet South Africa team. Health in South Africa: Changes and challenges since 2009. Lancet 2012;380(9858):2029-2043. [http://dx.doi.org/10.1016/ S0140-6736(12)61814-5] 